Historic, Archive Document

Do not assume content reflects current scientific knowledge, policies, or practices. 

2900 ACRES

1500 Acres in Orchards

A TREE IS A LIVING MONUMENT TO TIIE INDUSTRY OF TIIE PLANTER.

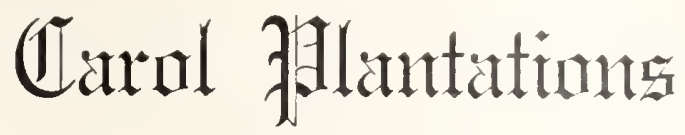

INCORPORATED
Our Nursery Specialies GRAFTED PECANS HUDDED SATSUMAS

A HOME IS NOT A REAL HONE UNTIL IT IS PLANTED.

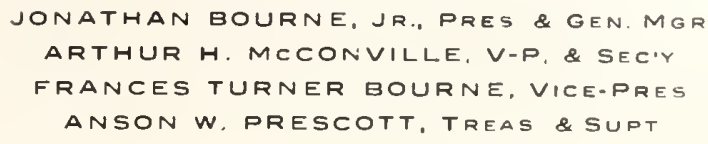

ARTHUR H. MCCONVILLE, V-P. \& SEC.Y

ANSON W, PRESCOTT, TREAS \& SUPT

\section{THE BEST KIND OF REFORESTATION}

\section{The Older a}

Pecan Orchard

Becomes,

the Less Care

It

Requires.

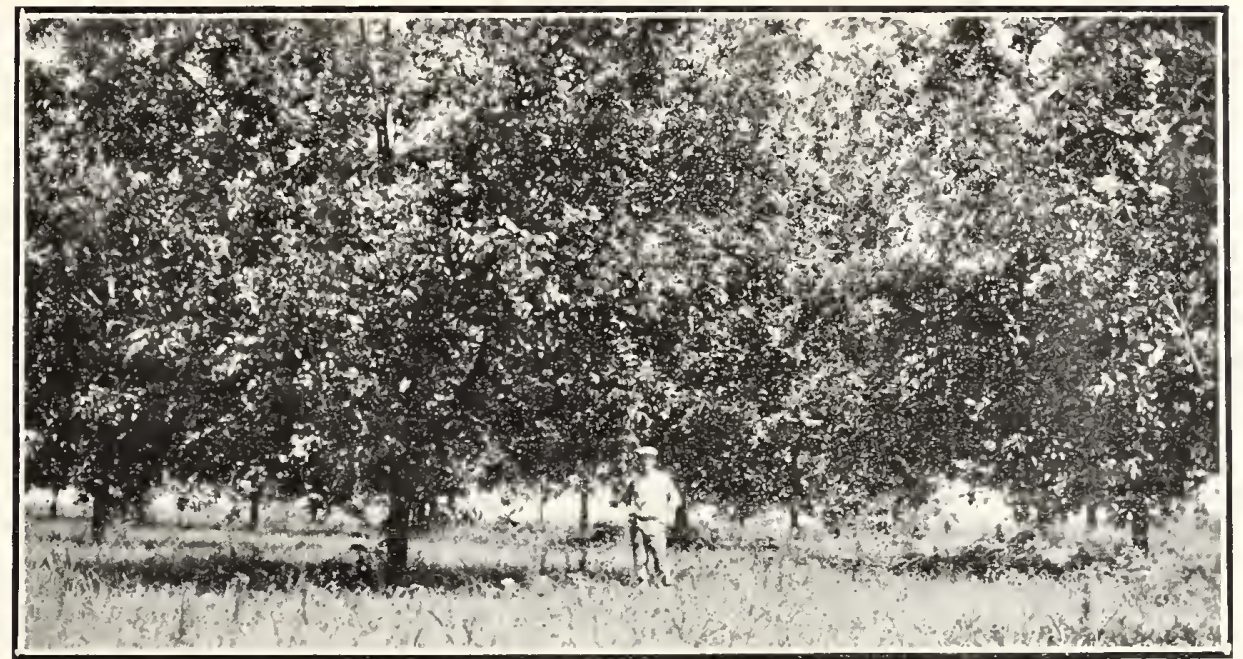

Truck Crops

were grown

between the

trees

for several

years.

II Year Old Pecan Orchard in Carol Plantations.

We are this season offering Southern planters the best pecan trees ever produced in our nurseries, ard, we thirk, the best that are to be had any. where. Our bid for your patronage is based upon quality and value-rot primarily ufen price.

It has been the practice of pecan nurseries to sell pecan trees by height, whereas height alore means relatively little. By pushing a tree with strong fertilizers we could produce a tall, slender tree of soft wood that we could sell at a low price and make a gcod profit curselves, but at a loss to our cus. tomers. We have never produced that kind of tree. We offer ycu caliper as well as height, firm wcod rather than soft, and branched trces rather than mere whips. You do not buy lumber, cloth, iron pire, rails $\mathrm{cr}$ wire by length alore. Pecan trees are abcut the only ccmmcdity the public has been accustemed to buy by ore dimersion measurement. The size of the trunk of a tree is no less important than the height, for it takes time to form a trunk. and the size of the trunk determines to a laroe degrae the san-carrying capacity of the tree

By producing a sturdy tree in the nursery, we save ycu time ard money in cevelcping an crchard. Don't buy trces by height alone.

\section{BRANCHED TREES SAVE TIME}

Both experience and observation convirce us that a tree should branch about five or six feet from tho ground-iust high enough to pcrmit cuiti. vation without injury to tree branches, and ours have been branched accordingly. This assures the planter a wel! balanced top which he might not get if he planted a "whip" and left it to develop a top afterward. We cull out the trees with unbalanced tops. You can save at least a year in development of a tree by planting a tree that has already formed its branch system in the nursery. We do not sell any branched tree with less than four branches, for a " $Y$ " fork is almost sure to split and be ruined. Our branched trees have from four to eight or more branches, from two to five feet long When the tree is transplanted these branches should be pruned part wav back, thus helping the root system to become established and forming addi. tional branches for nut production.

\section{QUALITY FIRST}

The Papershell Pecan is the acknowledged premier of all nuts. It is richest in food value and flavcr and brings the top price in the markets of the world. If competition becomes keen, it is quality that counts.

Soils suitable for pecan tree planting may usually be determined by observation of trees growing in the vicinity. Any soil successfullv producing seedling pecans or other trees may reasonably be expected to produce grafted papershells. Soil in which the water stands close to the surface is not suited to pecans Pecan trees are most commonly planted 60 feet apart, requiring 12 trees per acre. As a pecan tree is a deep rooted tree. truck or other crops may be planted between until the trees are large encugh to need the space.

Pecan trees sometimes bear nuts in the nursery, and exceptional trees may bear nuts a year or two after planting, which circumstance has led enthusiastic nurserymen to encourage planters to expect almost immediate returns from groves. Frankness requires that we declire to hold cut any such inducements. As a rule, pecan trees begin to bear about the fourth year after transplanting and with froper care will yield abcut ten pounds pcr tree at eight or nine years. Like any other long-lived tree, the pecan is not rapid in early development But this comparatively slow development is more than balanced by length of life and by the fact that the older the tree becomes the less attention it requires.

As pecan growing may be strongly recommended in connection with other farm operations, so it may be even more strongly recommended as a feature of every home. Innumerable instances may be observed of pecan trees planted in back yards, barn yards or poultry runs, where the soil is tramped hard all the year but where the pecan trees bear nuts regularly without any application of fertilizer or any care whatever. Those trees afford shade and add to the beauty of the home, at the same time that they provide food of a quality which the wealthiest feople delight to place upon their tables. 


\section{WE PRACTICE WHAT WE PREACH}

Carol Plantation Nurseries have been maintained for the purpose of supplying the needs of our own orchards as well as supplying other planters. Our budwood has been carefully selected from trees known to be bearing first-class nuts. Our confidence in the Pecan industry and in our nursery stock is indicated by the fact that we have planted over 14,000 Pecan trees. Our extensive experience and cur observation of the work of others are always t your disposal and we shall be glad to have you inspect our nurseries and orchards or consult our experts. Beginning now, you profit by what has been learncd during the experimental stage of the Pecan industry. By planting now you will in a few years have a fully grown orchard which will be a perpetual source of income at relatively little expense.

We were much impressed recently by the remark of an elderly farmer who had been all his life growing cotton and corn. He said that for fifteen years he had been talking of planting Pecan trees. He now realized that if he had planted trees when he began talking about it, he would now have a mature grove, at no appreciable cost, his land worth ten times its present value, and his income assured for the rest of his life. You will do well to profit by his experience.

\section{SATSUMA TREES}

Diameter-

Under $1 / 2$ inch

$1 / 2$ to $5 / 8$ inch

$5 / 8$ to $3 / 4$ inch

$3 / 4$ to $7 / 8$ inch

$7 / 8$ to 1 inch

1 inch and up.

\section{KUMQUATS}

Round or Oblong

PRICE LIST

$\$ .25$
.30
.45
.60
80
1.00

$\$ 1.00$

No order less than $\$ 2$ shipped. If by parcel post add 5 cents per tree.

\section{PECAN TREES}

\section{STUART - SuCCEsS}

Diameter-

$1-1 / 4$ inch

$1-1 / 2$ inch

$1-3 / 4$ inch

2 inch.

$2-1 / 4$ inch.

$\$ 1.00$

1.25

1.50

1.75

2.00

Trees 8 to 12 feet tall. All trees well branched and pruned ready to plant. No order less than $\$ 4$ shipped.
Prices subject to change without notice.

No pecan tree order less than $\$ 4$ shipped

Orders accepted subject to cance!lation if cir cumstances beyond our control prevent fulfillment.

Every tree should be pruned back before planting For the convenience of our customers, to save express charges and to lessen the danger of injury to the trees, we will prune all trees ready for plar, ing unless otherwise requested by the purchaser.

Our nurseries are regularly inspected by state er. tomologists and certified. We guarantee our trees to be true to variety, well dug, well packed and in good condition on arrival at destination. If not in good condition, register complaint with transporta tion agent and rotify us. Havirg no control over planting or care, we cannct be responsible for growth of trees. On delivery and acceptance in good condition, cur responsibility ends.

\section{Planting Instructions}

If trees cannot be planted immediately upon arrival, a trench should be dug large enough to receive the roots, the trees taken out of the bundle, the roots placed in the trench with tops sloping toward the South, and the roots covered with soil enough to prevent getting dry. Water frequently while thus heeled in

Get your holes ready before beginning to plant. Have the holes plenty large and deep. Pecan tree holes should be 3 feet deep and 3 feet across. When ready to plant, take out only a few trees at a time and keep the roots moist and covered from the wind. All broken or iniured portions of the roots should be trimmed to leave ends smooth. Trees should be planted about the depth they stood in the nursery. Spread the roots in a natural position, working under and around them fine top soil, rather than the soil that came out of the hole, and pressing the soil down firmly without bending the rcots downward.

When the hole is nearly filled pour in a pail or two of water to wash the soil against the roots and drive out air pockets. This is im portant. Then finish filling the hole with loose soil to serve as a mulch. We prefer putting fertilizer on top of the ground, around the tree, not closer than 8 to 10 inches, but some planters secure excellent resu!ts by digging the hole extra deep, throwing in three or fcur inches of well rotted manure, well mixed with soil, tramping it hard to exclude air covering it with well packed soil and then planting the tree above that Roots must not come in contact with strong fertilizer or they will be burned We have obtained excellent results by mixing a pound of cotton seed meal with the soil that fills the hole. Water the tree fre quently in dry woather the first season, and keep the grass and weeds hoed away for a distance of at least three feet. When watering a tree apply sufficient water at one time to moisten the soil to the bottom of the tap root. Light sprinkling does little good.

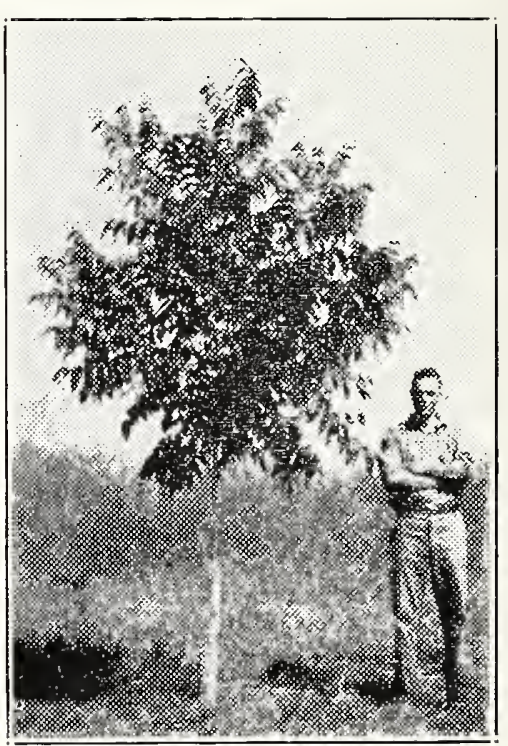

La Rue Steiner and one of the trees he bought from Carol Plantationsseven months after planting. Limbs were pruned back to 8 inches.
Grand Bay, Ala., August 15, 1931

In recent years we have purchased something like 600 pecan trees from you, mostlv Stuart variety, and have found them to be exceptionally clean, thrifty, well-rooted stock and in every case true to variety.

We wish also to commend at this time the accurate and conservative statements in your pecan literature regarding the age of bearing and production that may be expected from a well-cared-for pecan planting. These statements check very closely with our own experience as commercial pecan growers.

\section{Yours very truly,}

J. H. and A. R. KELLER.
Route 2, Box $210 \times$

Mobile, Ala., Sept. 9, 1931

I am pleased to inform you that all of the 55 grafted paper shell pecan trees I purchased from you are living and have made a wonderful growth. The root system of these trees when delivered was the greatest I have ever seen. I am so well pleased with these trees that I am enclosing an order for 160 more of your $\$ 1.50$ trees for delivery in December.

Yours truly,

\section{LA RUE STEINER}

I am pleased to advise you that all of the 355 pecan trees 1 purchased from you iast winter are living and have made a splendid growth. Part of them were planted on old, cultivated ground while the rest of them were planted on newly cleared land. 